\title{
INDIVIDUAL AND SOCIAL ASPECTS OF GLOBAL HUMAN RESOURCES STAFFING
}

\author{
Tatjana Ivanović \\ Faculty of Organizational Sciences, University of Belgrade, Serbia \\ tatjanaivanovic@hotmail.com
}

\begin{abstract}
Mimoza Bogdanoska Jovanovska
Faculty of Information and Communication Technologies - Bitola, St. Kliment Ohridski University in Bitola, Republic of Macedonia

mimoza.jovanovska@fikt.edu.mk
\end{abstract}

\begin{abstract}
Globalization has become one of the most influential trends in the business environment in recent decades. Since companies started to spread their operations beyond national borders and to employ people originating from different countries, new challenges for human resource management have emerged. This paper ascertains, summarizes, and explains specificities of staffing in an international context, theories dealing with global staffing, and basic approaches to the staffing process in order to identify various determinants which may affect the process of choosing an appropriate staffing policy in multinational companies, i.e., the decision-making process about staffing of global managers in an international business environment. Various research has shown that the success of a global manager depends not only on the employee's personality and adaptability to different cultures, but also on the willingness and readiness of his or her family members to move to a foreign country. The conclusion of this paper is that staffing decisions for global managers, in addition to technical competencies and expertise, should take into consideration different individual and social factors (i.e., different personal attributes and skills, as well as specific requirements of a manager's family) and that selection procedures should be customized to enable determining the best individuals for managerial positions in foreign subsidiaries of multinational companies, who will be able to fit into the new environment quickly and easily and perform the job in an expected manner.
\end{abstract}

Keywords: human resource management, staffing, global manager, multinational company, international assignment

\section{INTRODUCTION}

Human resource management has long been considered by both academics and professionals to be a very important determinant for achieving organizational success. Over time this function has developed from a support organizational function to one of the most significant strategic functions of an organization. Therefore, human resource management is currently more and more considered not only as a set of policies and practices that need to be incorporated into corporate strategy, but as a key component of this strategy.
Globalization became one of the most influential trends in the business environment in recent decades. This trend was accompanied by extensive expansion of operations of companies outside the parent countries, which resulted in increasing need for effective management of their foreign subsidiaries. Another consequence of accelerated globalization is significant growth of interest in human resource management in international context. Interest in international human resource management, as an important dimension of international management, has been rising since the beginning of the 1990s. Expansion of operations 
across national boundaries and employment of human resources from different countries has brought new challenges for human resource management functions. Effective international human resource management is more and more being perceived as a key source of competitive advantage of multinational companies (MNCs) and as a significant indicator of success or company failure in the international environment (Scullion \& Starkey, 2000). However, even though globalization brought many advantages, it also brought certain difficulties that companies encounter on a day-to-day basis in the global business environment, particularly in the human resource management area.

A current prevailing opinion is that effective human resource management may provide a competitive advantage to multinational companies. Even though all aspects of human resource management are important, staffing is often seen as a key human resource management activity in the international environment. Global staffing may be defined as "critical issues faced by multinational companies regarding employment of human resources originating from parent country, country in which foreign subsidiary is located, or third country (in which nor headquarters nor subsidiary is located) in order to fill key positions in the headquarters and foreign subsidiaries" (Scullion \& Collings, 2006: 3).

Therefore, international staffing mainly refers to the selection of the best individuals for particular positions in subsidiaries based on employee nationality. This approach to staffing is supposed to enable achievement of various strategic goals, such as attaining and maintaining of global integration, control and coordination, providing adequate response to business conditions in a foreign country, and transfer of knowledge within the company beyond national borders (Colakoglu, Tarique, \& Caligiuri, 2009). Certainly, the decision about the best combination of local and parent-country employees who will enable achievement of organizational goals in the most effective manner represents a major challenge for a multinational company (Caudron, 1997). This is why it is important to identify, explain, and understand different problems which multinational companies may encounter in different countries in the process of staffing of human resources originating from different countries and cultures.
This is a review paper, which ascertains, summarizes, and explains specificities of staffing in an international context, theories dealing with global staffing, and basic approaches to the staffing process in order to identify various individual and social determinants which may affect the process of choosing an appropriate staffing policy in multinational companies, i.e., the decision-making process about staffing of global managers (expatriates) in the international business environment.

\section{THEORETICAL BACKGROUND}

\subsection{Theories on global human resources staffing}

Among the numerous theoretical approaches to human resources staffing in the global business environment are the resource-based theory, agency theory, transaction costs theory, and organizational learning theory.

\subsubsection{Resource-based theory}

During the 1990s it was asserted assertion that human resources may be a source of competitive advantage of an organization. Achieving a competitive advantage represents a crucial objective of every company, which cannot be accomplished without appropriate human resource management. Resource-based theory assumes that an organization can be successful only if it can achieve and maintain competitive advantage (Jackson \& Schuler, 1995).

As far as staffing decisions for international managers are concerned, this approach particularly emphasizes input, referring to competencies of managers, with a special focus on advantages which managers may bring to a multinational company (Tharenou \& Harvey, 2006). Because multinational companies operate in different business environments, this approach explains why companies need to transfer competencies worldwide even though human resources may provide a competitive advantage to a company, such an advantage can be achieved only if the company is able to use the knowledge, skills, and capabilities of its employees in the proper way (Brewster, Sparrow, \& Vernon, 2007). 
The resource-based approach is based on a viewpoint that expatriate managers primarily may add value to a company because they provide training and development of local employees in foreign subsidiaries. In addition, international assignments contribute to the development of managers, and satisfy both their own and the organization's needs (Bruning, Bebenroth, \& Pasch, 2011). Working on international assignments, expatriates develop existing skills and acquire new skills, which results in the creation of unique and valuable competencies in the company. Similarly, in addition to global managers, local managers in a foreign country may also bring value to the company - because they are familiar with the local culture, customs, and institutions, they may contribute to the increase in motivation of local employees and may encourage development of local talent (which is rather consistent with the reasons specified in the transaction costs theory).

\subsubsection{Transaction costs theory}

Initial research into doing business in an international context was primarily based on economic theories, such as transaction costs theory. This theory is focused on transaction costs which may increase the company value. Hence, it takes into consideration the cost of human resource management activities, assuming that organizations tend to decrease transaction costs (Aycan, 2005).

With regard to staffing in an international context, this theory focuses on the costs related to the transfer of global managers, employment and training of local employees, development of local and international markets, familiarization with the culture and customs of the foreign country in which a subsidiary is located, and control of the foreign subsidiaries. A company may endeavor to decrease transaction costs by employing local managers who are familiar with local competitors, culture, and language.

According to this theory, the value that global managers may bring to a company results from the fact that they perform strategic organizational functions, enable effective communication between the headquarters and the foreign subsidiary, and solve crisis situations in the interest of the headquarters; whereas the value which may be brought by local managers results from the reduction of costs related to human resource management (Bruning et al., 2011).

\subsubsection{Agency theory}

In recent years, agency theory has been widely used to explain different phenomena regarding operations of companies in an international context. The theory is similar to transaction costs theory, and it gives particular attention to the relationship between principal and agent - in the case of multinational companies, the principal refers to the headquarters, and the agent refers to a foreign subsidiary. A principal entrusts a specific job to an agent with an aim to accomplish a desired result; grants certain authority to the agent; and invests certain assets, expecting their return with increased value; whereas the agent primarily tends to reduce conflict with the principal.

Regarding global staffing, agency theory is primarily focused on examination of the manner in which a manager (global or local) tries to harmonize operations of the subsidiary with the multinational company headquarters (O'Donnell, 2000). Hence, functions of global and local managers which are important according to this theory are those which should harmonize practices applied in foreign subsidiaries with the goals and expectations of the headquarters. In this respect, benefits which a global manager can bring to a company include activities related to the process of establishment of a subsidiary in a foreign country, training and development of local employees, coordination of the operation of foreign subsidiaries in compliance with the requirements of the headquarters, care for the loyalty of a subsidiary to the parent company, and providing feedback from a subsidiary to the headquarters, whereas local managers in foreign subsidiaries are expected to transfer information about the local culture and local structures in order to facilitate the process of harmonization of policies and practices of the headquarters and the foreign subsidiary (Bruning et al., 2011).

Furthermore, the principal tends to monitor the work of managers in foreign subsidiaries and to collect information about their behavior and decisions with an aim to increase efficiency and reduce 
the possibility that the agent's actions are not consistent with the interests of the principal. Because keeping direct control of foreign subsidiaries is very difficult (due to the geographical distance between principal and agent), companies often tend to fill top management positions in subsidiaries with parent-country employees in order to facilitate control and coordination of the subsidiaries' activities.

\subsubsection{Organizational learning theory}

This theory considers organizational learning to be a fundamental precondition for the achievement of a sustainable competitive advantage of a company (Venaik, Midgley, \& Devinney, 2005). In order to maintain a competitive advantage, companies need to adapt over time in order to respond properly to specific requirements of the environment. Unlike the previously explained theoretical approaches to international staffing, the theory of organizational learning does not list specific functions of global and local managers which may benefit multinational companies, but emphasizes the importance of the dynamic role of top managers in the process of the development of a foreign subsidiary.

\subsection{Selection of staffing policy in multinational companies}

Dowling and Welch (2006) suggested that the approach which will be used by a multinational company to fill positions in its foreign subsidiaries depends on the general policy regarding staffing for key positions in the headquarters and foreign subsidiaries, limitations regarding employment policies in the foreign country, and the availability of the required human resources.

Selection of a staffing policy depends primarily on organizational variables. Most researchers agree that company characteristics significantly influence selection decisions for global managers who will be sent to foreign subsidiaries (Colakoglu \& Tarique, 2006). The decision about the particular approach which will be used for the staffing process basically depends on the degree of global maturity of a company - companies with a higher level of global maturity mainly tend to employ local managers in their foreign subsidiaries, i.e., they tend to use global managers to a lesser extent (Jacobini, 2005). Additionally, the internationalization phase may significantly affect decisions about global staffing strategies (Welch, 1994; Vance \& Paik, 2006; Reiche, 2007). Various researchers have also identified other organizational factors that are significant in making the decision of an appropriate approach to staffing in an international context, such as industry type (Welch, 1994; Harzing, 2004; Reiche, 2007), organizational strategy and structure and organizational culture (Welch, 1994), business (competitive) strategy of a multinational company (Tarique, Schuler, \& Gong, 2006; Vance \& Paik, 2006; Reiche, 2007), existence of adequate training programs for expatriate managers (especially in terms of crosscultural adaptation), existence of individual and organizational development plans, existence of an adequate repatriation program and an appropriate compensation package for managers (Harvey \& Novicevic, 2001), subsidiary characteristics (Reiche, 2007) [such as subsidiary age, size and performance (Harzing, 2004)], and prior experience of a company in a specific foreign market (Vance \& Paik, 2006).

Harvey and Novicevic (2001) suggested that some systemic factors may affect the decision about the approach to global staffing - flexibility of the international human resource management system, effectiveness of the performance management system for global managers, the technique of negotiation with candidates for expatriation regarding the terms of the contract, degree of application of technology, etc.

In addition to these factors, staffing policy may also be influenced by contextual variables, primarily characteristics of the parent and foreign countries, as well as specificities of the foreign-country environment (i.e., the legal and regulatory system, and cultural differences between parent and foreign country). Hence, many factors may strongly influence the choice of a particular staffing policy for global managers: social and cultural characteristics of the foreign country, i.e., differences in culture, economy, and language between the parent and foreign countries (Harvey \& Novicevic, 2001; Harzing, 2004; Tarique et al., 2006; Vance \& Paik, 2006; Reiche, 2007); limitations in the area of human resource management imposed by the foreign-country government (Harvey \& Novicevic, 2001; Vance \& Paik, 2006); and political risk in the foreign country (Harzing, 2004). 
Other situational factors which may influence the staffing philosophy and which may even prevail over the organizational variables include the nature, location, and period of the international assignment (Barhem, 2008); the financial assets a multinational company may provide for international staffing; economic trends and conditions (Vance \& Paik, 2006); the availability of qualified candidates willing to accept international assignments (Welch, 1994; Vance \& Paik, 2006); and the time available for completion of the selection process (Welch, 1994).

\subsection{Factors influencing selection of global managers}

Companies have continuously been making efforts to identify factors which may influence success or failure of global managers in order to develop criteria to use to select candidates for those positions. After a company decides on a particular approach to staffing of managers for international assignments, it is necessary to include various variables which may affect the success of expatriate managers, primarily individual and social factors, in order to perform the selection process in the best possible way.

\subsubsection{Individual factorsTop of Form}

Success of global managers is strongly influenced by individual factors. Global managers are primarily expected to possess specific technical and managerial skills (Harvey \& Novicevic, 2001; Dowling \& Welch, 2006), i.e., to be experts in their field of work and capable of performing required tasks in international assignments. In addition, it is necessary that they have a history of successful past performance in managerial positions. However, even though numerous studies have assumed that successful performance in the domestic environment and possession of required technical competencies ensure success in international assignments (Orlić, 2005), emphasizing solely expertise and technical competencies as crucial selection criteria for expatriate managers will not always correctly predict their success in international assignments. Good past performance in the domestic environment may often lead to mistaken expectations regarding the success of managers in an international environment.
Although many other factors which may influence success of global managers have been identified, the belief that technical or functional expertise should be key selection criteria for global managers has not been overcome yet - most multinational companies even now base their staffing decisions for international assignments primarily on those criteria.

Because global managers need to perform a wider range of activities and usually have greater responsibilities compared to their job in the parent country, they are usually required to possess higher levels of skills and qualities for international assignments than for work in the domestic environment (Harris \& Brewster, 1999). This is why companies which operate successfully in an international environment tend to select global managers who possess not only necessary expertise and technical skills, but also the ability to adapt easily to living and working in different social, cultural, and legal contexts (Black \& Gregersen, 1999).

Many researchers claim that personal characteristics may predict the success of an expatriate manager in an international assignment to a certain degree. Some individuals possess characteristics which may help them adapt successfully to life and work in a foreign country, whereas others will experience failure in international assignments (Caligiuri, 2000). Harvey and Novicevic (2001) summarized the individual characteristics of a successful global manager:

- The Big Five personality characteristics - extroversion, agreeableness, conscientiousness, emotional stability, and openness/intellect

- soft social skills - skills which are not directly related to technical and functional expertise, such as flexibility or the ability to adapt to a new environment (Arthur \& Bennett, 1995; Harvey, 1996; Dowling \& Welch, 2006; Harvey \& Moeller, 2009; Templer, 2010), sensitivity to other cultures, openness, familiarity with the foreign country's language (Dowling \& Welch, 2006; Barhem, 2008), and communication skills (Harris \& Brewster, 1999)

- other skills - global awareness, cultural empathy, negotiation skills in an international environment, ethical understanding of doing business in foreign countries, and self-confidence. 
Because expatriates interact with people from other cultures on a day-to-day basis, Caligiuri (2000) concluded that their most important traits include extroversion, agreeableness, and emotional stability (i.e., a manager's ability to remain calm when facing a different culture and to perform his or her job effectively even in such circumstances) (Van der Zee, Atsma, \& Brodbeck, 2004). Because adaptation to another culture may be very stressful, emotional stability represents an important characteristic of successful global managers (Baumgarten, 1995; Dowling \& Welch, 2006; van Woerkom \& de Reuver, 2009). Research suggests that cultural empathy (i.e., an individual's interest in other people and ability to understand feelings, thoughts, and behavior of people from different cultural groups) represents one of the crucial traits of a successful global manager (Harvey, 1996; Van der Zee et al., 2004; Dowling \& Welch, 2006; Harvey \& Moeller, 2009). Cultural empathy is closely related to openness or sensitivity to other cultures (Hammer, Bennett, \& Wiseman, 2003), which is a necessary precondition for effective communication between a global manager and people from other cultures which he or she meets in a foreign country (Arthur \& Bennett, 1995; Harvey, 1996; Black \& Gregersen, 1999; Harvey \& Moeller, 2009; Templer, 2010). Identification and interaction with locals are also important determinants which may affect adaptation to different social and cultural environments (Black \& Gregersen, 1999; Barhem, 2008). Tye and Chen (2005) concluded that stress tolerance makes the difference between an average and an exceptional global manager - because adaptation to a different culture may be very stressful, it is expected that individuals who possess the ability to cope with stress will handle these situations more easily.

Many researchers claimed that cross-cultural skills are the most important predictor of global manager success, i.e., possessing various abilities which enable an expatriate to work successfully in a new environment, such as familiarity with a foreign culture or interest in a local culture (Barhem, 2008; Harvey \& Moeller, 2009); motivation, i.e., a positive attitude toward an international assignment (Arthur \& Bennett, 1995; Baumgarten, 1995; Dowling \& Welch, 2006); initiative (Baumgarten, 1995; Harvey \& Moeller, 2009); leadership skills
(Baumgarten, 1995; Templer, 2010); sociability; a positive image of oneself (Harvey \& Moeller, 2009); a potential for learning foreign language (Harvey, 1996); etc.

\subsubsection{Social factors}

Global movement of employees in multinational companies may lead to serious social issues, primarily in terms of the adaptation of their family members to the foreign country environment. Many studies suggested that the success of a manager in an international environment strongly depends on his or her family requirements.

Multinational companies usually consider an international assignment to be a long-term assignment of a manager in a foreign country, i.e., an assignment in which a manager is relocated to a foreign country with his or her family (Mayerhofer, Hartmann, \& Kollinger, 2004) for a period longer than one year, usually between three and five years. A manager who is transferred to a foreign country for a long period usually moves with his or her family, which significantly increases the complexity of this process. This is why it is necessary to give special attention to the needs and requirements of the family of the employee whom the company intends to send abroad.

Transferring to a new and unfamiliar environment may disrupt existing everyday habits of the employee and his or her family, which may result in increased dissatisfaction and stress of the individual or the whole family, and in some cases may even lead to their premature return to the parent country. Issues related to adaptation of the expatriate and his or her family to a foreign country may be very serious - particularly in the case of large cultural and religious differences between the parent and foreign countries (Harzing, 2001).

According to many studies, insufficient attention to a manager's spouse (or partner) and children often results in lesser success of the manager in a foreign assignment, and represents one of the most common reasons for failure, or the premature return of the manager to the parent country (Anderson, 2005; Dowling \& Welch, 2006). This is why family requirements should be considered as one of 
crucial factors for selection of candidates for positions in foreign subsidiaries, with the aim to increase the chances for successful performance of managers in a global environment (Arthur \& Bennett, 1995; Dowling \& Welch, 2006).

Failure in an international environment often occurs due to the inability of an employee (or his or her partner) to adapt to the foreign country (Tung, 1981), i.e., to a different, strange environment, and to cope with the stress caused by relocation and a changed lifestyle. Similarly, Dowling et al. (1999) suggested that issues related to adaptation of a manager's family to a foreign environment represent the main reason for failure of managers in international assignments, whereas Tung (1987) listed the following reasons for failure of global managers:

1. spouse's inability to adapt to a different physical or cultural environment

2. manager's inability to adapt to a different physical or cultural environment

3. other family-related issues

4. personal characteristics of a manager (i.e., emotional immaturity).

Various social determinants need to be considered in the selection of a manager who will be sent to an international assignment. Relocation to a foreign country may lead to social and psychological alienation of the expatriate and his or her family. Building new social networks, joining particular social activities, and making new acquaintances and friends in the foreign country may be very difficult both for the manager and his or her family members.

Special attention needs to be paid to issues related to the influence of international assignment on the spouse's (partner's) career. An issue usually emphasized in this context is dual careers and the spouse's concerns regarding discontinuation of their career. It often happens that the spouse has to leave a job in the parent country and then fails to receive work permission or to find an appropriate job in the foreign country, which may result in stagnation in their career and increased dissatisfaction.

Moreover, serious problems may also appear in terms of education of children in the foreign country - finding appropriate schools, adaptation of children to a new school, their effort to incorporate into the group and become used to a different education system, etc.

\section{DISCUSSION AND CONCLUSION}

Many researchers have attempted to identify the relationship between a manager's success in an international environment and specific individual characteristics and skills and family requirements.

Tungli and Peiperl (2009) examined 136 MNCs from four different countries - the US, the UK, Germany, and Japan - and concluded that technical skills were among the highest-ranked selection criteria for international managers. Their findings match the results of Peterson et al. (2000), who found that UK and US companies select expatriates primarily based on technical and professional skills, as well as interpersonal skills. Managerial talent and technical knowledge represent key selection criteria in German and Japanese MNCs. The most important selection criteria in US MNCs were communication and adaptability/flexibility; the latter was rated as very important for German and Japanese MNCs.

Bhskar-Shrinivas et al. (2005) conducted a meta-analysis of over 50 determinants and of expatriate success using data from 8,474 expatriates in 66 studies and found that some of the most obvious determinants, such as previous international experience and speaking the host-country language, have the least important effects on expatriate success. They concluded that the most important determinants of expatriate success included adjustment of the spouse, family adjustment, and relational skills. Furthermore, the ability of the international manager to believe in his or her own actions was found to be crucial in achieving success in the assignment. Additionally, they found that the support of the family members and their adjustment to the foreign location was one of the strongest predictors of expatriate success.

According to the findings of various studies, it may be concluded that successful global managers should be extroverted, ready to make acquaintances with locals, flexible, and innovative and creative; they should show understanding and respect for different cultural norms and attitudes, and use 
a collaborative negotiation style in communication with local nationals and local employees (Black \& Gregersen, 1999); and their family members should express willingness and readiness to transfer to a foreign country; which all should enable them to adapt to the new environment more quickly and easy.

If all social issues are not addressed quickly and appropriately, the employee's job (as well as his whole family's lives) may become very unpleasant. Because the success of an international assignment largely depends on the willingness and readiness of the manager and his or her family to accept the international assignment, which will require transferring to a foreign country for a certain period (Harvey \& Novicevic, 2001), the selection decision must be a mutual decision of the company, the employee, and his or her family. Because the support of the partner and family is crucial for the employee's success in an international assignment, companies should examine all family-related issues which may arise even during the recruitment process, before the final decision to transfer an employee abroad is made. In order to avoid, or at least mitigate, some potential difficulties that the manager's family may face in the foreign country, it is very important to include the employee's family in the selection process. A manager's spouse (or partner) should be interviewed in order to identify possibilities to avoid or meet numerous challenges and difficulties which the manager's family could encounter in the foreign country.

However, even though research has found that in addition to job-related and environmental factors, personal attributes and cross-cultural skills are important predictors of the success of global managers, companies still tend to make selection decisions based solely on job knowledge and technical competencies of candidates. By doing this, they increase the risk of the manager's failure or unsatisfactory performance (as well as that of the department under his or her responsibility), or decreased motivation of his or her subordinates (Templer, 2010). This is why the selection decision process should include additional determinants, particularly individual and social attributes, and selection procedures should be adjusted in order to find the best individuals for managerial positions in foreign subsidiaries of multinational companies.

\section{EXTENDED SUMMARY / IZVLEČEK}

Globalizacija je v zadnjih desetletjih postala ena izmed najvplivnejših trendov v poslovnem okolju. Vse odkar so podjetja začela širiti svoje poslovanje izven meja domače države in zaposlovati ljudi iz tujine, so se pojavili novi izzivi na področju managementa človeških virov. Prispevek ugotavlja, povzema in pojasnjuje posebnosti zaposlovanja v mednarodnem kontekstu, teorije, ki se ukvarjajo $z$ globalnim zaposlovanjem, in osnovne pristope $k$ procesu zaposlovanja. Omenjeno napravi z namenom opredelitve različnih determinant, ki lahko vplivajo na postopek izbora ustrezne kadrovske politike $v$ multinacionalnih družbah in na proces odločanja o kadrovanju globalnih menedžerjev $v$ mednarodnem poslovnem okolju. Različne raziskave so pokazale, da uspeh globalnega vodje ni odvisen samo od osebnosti in prilagodljivosti različnim kulturam, ampak tudi od želje in pripravljenosti njegovih/njenih družinskih članov, da se preselijo v tujo državo. Končna ugotovitev raziskave je, da morajo kadrovske odločitve za globalne menedžerje poleg tehničnih kompetenc in strokovnega znanja upoštevati tudi različne individualne in družbene dejavnike (tj. različne osebnostne lastnosti in spretnosti posameznika ter posebne zahteve družinskih članov). Nadalje avtorji ugotavljajo, da je potrebno izbirne postopke prilagoditi in tako omogočiti določitev najboljših posameznikov za vodstvene položaje v tujih hčerinskih družbah multinacionalnih podjetij, ki se bodo lahko hitro in preprosto vključili v novo okolje in opravili delo na pričakovani način. 


\section{REFERENCES}

Anderson, B. (2005). Expatriate Selection. Good Management or Good Luck? International Journal of Human Resource Management, 16 (4), pp. 567-583.

Arthur, W. \& Bennett, W. (1995). The International Assignee: The Relative Importance of Factors Perceived to Contribute to Success. Personnel Psychology, 48 (1): pp. 99-114.

Aycan, Z. (2005). The Interplay between Cultural and Institutional/structural Contingencies in Human Resource Management Practices. International Journal of Human Resource Management, 16 (7), pp. 1083-1119.

Barhem, B. (2008). Are Global Managers Able to Deal with Work Stress. Journal of Accounting, Business \& Management, 15 (1), pp. 53-70.

Baumgarten, K. (1995). Training and Development of International Staff. A.-W. Harzing and J. van Ruysseveldt, Joris (Eds.), International Human Resource Management, London: Sage.

Bhaskar-Shrinivas, P., Harrison, D. A., Saffer, M. A., \& Luk, D. M. (2005). Input-Based and Time-Based Models of International Adjustment: Meta-Analytic Evidence and Theoretical Extensions, Academy of Management Journal 48(2), pp. 257-81.

Black, S. \& Gregersen, H. (1999). The Right Way to Manage Expats. Harvard Business Review, 77 (2), pp. 52-63.

Brewster, C., Sparrow, P. \& Vernon, G. (2007). International Human Resource Management (2nd ed.). London, UK: CIPD.

Bruning, N., Bebenroth, R. \& Pasch, W. (2011). Valuing Japan-based German Expatriate and Local Manager's Functions: Do Subsidiary Age and Managerial Perspectives Matter? International Journal of Human Resource Management, 22 (4), pp. 778-806. doi:10.1080/09585192.2011.555123

Caligiuri, P. (2000). The Big Five Personality Characteristics as Predictors of Expatriate's Desire to Terminate the Assignment and Supervisor-Rated Performance. Personnel Psychology, 53 (1), pp. 67-88

Caudron, S. (1997). World Class Execs. Industry Week, 246 (22): pp. 60-66.

Colakoglu, S. \& Tarique, I. (2006). Subsidiary Staffing and Performance: A Fit Perspective. Academy of Management Annual Meeting Proceedings, pp. 1-6.

Colakoglu, S., Tarique, I. \& Caligiuri, P. (2009). Towards a Conceptual Framework for the Relationship between Subsidiary Staffing Strategy and Subsidiary Performance. International Journal of Human Resource Management, 20 (6), pp. 1291-1308.

Dowling, P. \& Welch, D. (2006). International Human Resource Management: Managing People in a Multinational Context (4th ed.). London, UK: Thomson.
Hammer, M., Bennett, M. \& Wiseman, R. (2003). Measuring Intercultural Sensitivity: The Intercultural Development Inventory. International Journal of Intercultural Relations, 27 (4), pp. 421-443.

Harris, H. \& Brewster, C. (1999). The Coffee Machine System: How International Selection Really Works. The International Journal of Human Resource Management, 10 (3), pp. 488-504.

Harvey, M. (1996). The Selection of Managers for Foreign Assignments: A Planning Perspective. Columbia Journal of World Business, 31 (4), pp. 102-118.

Harvey, M. \& Moeller, M. (2009). Expatriate Managers: A Historical Review. International Journal of Management Reviews, 11 (3), pp. 275-296.

Harvey, M. \& Novicevic, M. (2001). Selecting Expatriates for Increasingly Complex Global Assignments. Career Development International, 6 (2), pp. 69-86.

Harzing, A.-W. (2001). Who's in Charge? An Empirical Study of Executive Staffing Practices in Foreign Subsidiaries. Human Resource Management, 40 (2), pp. 139-158.

Harzing, A.-W. (2004). Composing and International Staff. A.-W. Harzing and J. van Ruysseveldt (Eds.), International Human Resource Management (2nd ed.), London, UK: Sage.

Jackson, S. \& Schuler, R. (2003). Managing Human Resources through Strategic Partnerships (8th ed.). Cincinnati, OH: South-Western.

Jacobini, D. (2005). Expatriate Administration: New Realities and HR Challenges. Employee Benefit News, 19 (3), pp. 11-11.

Krstić, B. (2007). Management of Human Resource Performance as Determinant of Creating Firm Value and Competitive Advantage, Themes - Journal for Social Research, XXXI (2), pp. 315-328.

Mayerhofer, H., Hartmann, L., Michelitsch-Riedl, G. \& Kollinger, I. (2004). Flexpatriate Assignments: A Neglected Issue in Global Staffing. International Journal of Human Resource Management, 15 (8), pp. 1371-1389.

O'Donnell, S. (2000). Managing Foreign Subsidiaries: Agents of Headquarters, or an Independent Network? Strategic Management Journal, 21 (5), pp. 525-548.

Orlić, R. (2005). Kadrovski menadžment [Personnel Management]. Belgrade: Zpran Damnjanović i sinovi.

Reiche, S. (2007). The Effect of International Staffing Practices on Subsidiary Staff Retention in Multinational Corporations. International Journal of Human Resource Management, 18 (4), pp. 523-536.

Scullion, H. \& Collings, D. (2006). Global Staffing. London, UK: Routledge.

Scullion, H. \& Starkey, K. (2000). In Search of the Changing Role of the Corporate Human Resource Function in the International Firm. International Journal of Human Resource Management, 11 (6), pp. 1061-1081. 
Tarique, I., Schuler, R. \& Gong, Y. (2006). A Model of Multinational Enterprise Subsidiary Staffing Composition. International Journal of Human Resource Management, 17 (2), pp. 207-224.

Templer, K. (2010). Personal Attributes of Expatriate Managers, Subordinate Ethnocentrism, and Expatriate Success: A Host-country Perspective. International Journal of Human Resource Management, 21 (10), pp. 1754-1768.

Tharenou, P. \& Harvey, M. (2006). Examining the Overseas Staffing Options Utilized by Australian Headquartered Multinational Corporations. International Journal of Human Resource Management, 17 (6), pp. 1095-1114.

Tung, R. (1981). Selecting and Training of Personnel for Overseas Assignments. Colombia Journal of World Business, 16 (1), pp. 68-78.

Tung, R. (1987). Expatriate Assignments: Enhancing Success and Minimizing Failure. Academy of Management Executive, 1 (2), pp. 117-125.

Tungli, Z., \& Peiperl, M. (2009). Expatriate Practices in German, Japanese, U.K., and U.S. Multinational Companies: A comparative Survey of Changes, Human Resource Management, Vol 48 (1), pp. 153-171.

Tye, M. \& Chen, P. (2005). Selection of Expatriates: Decision-Making Models Used by HR Professionals (cover story). Human Resource Planning, 28 (4), pp. 15-20.

Van der Zee, K., Atsma, N. \& Brodbeck, F. (2004). The Influence of Social Identity and Personality on Outcomes of Cultural Diversity in Teams. Journal of Cross-Cultural Psychology, 35 (3), pp. 283-303.

Van Woerkom, M. \& de Reuver, R. (2009). Predicting Excellent Management Performance in an Intercultural Context: A Study of the Influence of Multicultural Personality on Transformational Leadership and Performance. International Journal of Human Resource Management, 20 (10), pp. 2013-2029.

Vance, C. \& Paik, Y. (2006). Managing a Global Workforce: Challenges and Opportunities in International Human Resources Management. New York, NY: Armonk.

Venaik, S., Midgley, D. \& Devinney, T. (2005). Dual Paths to Performance: The Impact of Global Pressures on MNC Subsidiary Conduct and Performance. Journal of International Business Studies, 36 (6), pp. 655-675.

Welch, D. (1994). Determinants of International Human Resource Management Approaches and Activities: A Suggested Framework. Journal of Management Studies, 31 (2), pp. 139-164. 